\title{
The Marine Isotopic Stage 3 (MIS 3) in Valleys of the Undulated Pampa, Buenos Aires Province, Argentina
}

\author{
Adriana María Blasi, Carola Castiñeira Latorre, \\ Gabriela Catalina Cusminsky and Ana Paula Carignano
}

\begin{abstract}
A depositional unit called DU2 identified for the period MIS 3 (ca$30,000-60,000$ year B.P.) formed by only one sedimentary facies (F3) was found in the Luján and Salto-Arrecifes rivers basins. F3 is a fluvio-lacustrine unit that overlies in erosive unconformity over eolian sediments with ages of $56,400 \pm 6500$ and 50,400 $\pm 10,200$ years B.P. and is unconformably covered by another eolian vitroclastic sandy loess deposit, dated as 32,000 \pm 4000 years (Infrared Stimulated Luminescence, IRSL) (Blasi et al. 2009a). It represents the recurrence of ephemeral fluvial streamlets and the development of temporary pools by subsequent damming of channels. It corresponds lithologically to sandy muddy gravel, gravelly muddy sand, gravelly mud olive to pale olive, feldspar and quartz sands, bearing extinct mollusks such as Heleobia ameghini and Diplodon lujanensis. Radiocarbon chronologies obtained on monospecific samples of Cyprideis salebrosa hartmanni and Heleobia ameghini yielded ages of $37,710 \pm 840$ years ${ }^{14} \mathrm{C}$ B.P. and $>40,000$ years ${ }^{14} \mathrm{C}$ B.P., respectively. Furthermore, the age obtained through the IRSL technique was of $44,000 \pm 6500$ years. Based upon the analyzed bioproxies (malacological, phytoliths and diatomological content) F3 accumulated under variable climatic conditions, ranging from temperate to colder and from subhumid to drier. According to the exhaustive stratigraphic identification, it is proposed that in N-E Buenos Aires Province, the so-called Undulated Pampa region, the
\end{abstract}

A.M. Blasi (ه)

CIC- División Mineralogía, Sedimentología \& Petrología, Museo de La Plata,

Universidad Nacional de La Plata, Paseo Del Bosque S/N, 1900 La Plata, Argentina

e-mail: ablasi@fcnym.unlp.edu.ar

C.C. Latorre

CONICET-División, Mineralogía, Sedimentología \& Petrología, Museo de La Plata,

Universidad Nacional de La Plata, Paseo Del Bosque S/N, 1900 La Plata, Argentina

G.C. Cusminsky

INIBIOMA-CONICET, Centro Regional Universitario Bariloche,

Universidad Nacional Del Comahue, Quintral 1250, 8400 San Carlos de Bariloche, Argentina

A.P. Carignano

CONICET-División Paleozoología Invertebrados, Facultad de Ciencias Naturales Y Museo,

Universidad Nacional de La Plata, Paseo Del Bosque S/N, 1900 La Plata, Argentina

(C) Springer International Publishing Switzerland 2016

G.M. Gasparini et al. (eds.), Marine Isotope Stage 3 in Southern

South America, $60 \mathrm{ka}$ B.P.-30 ka B.P., Springer Earth System Sciences,

DOI 10.1007/978-3-319-40000-6_7 
sediments that were accumulated during MIS3 occur only in the central portion of the studied fluvial basins. This prompted two hypotheses related to the existence of a particular drainage pattern for the Late Pleistocene, different from the present one, and subsequent tectonic controls that allowed the identification of DU2 sediments only in some of the analyzed sections.

Keywords Undulated Pampa region - Buenos Aires Province, Argentina - MIS 3 - Late Pleistocene - Infrared stimulated luminescence (IRSL) - Paleoenvironment reconstruction - Paleoclimatic conditions - Fluvial and lacustrine sedimentation Luján river - Salto-Arrecifes rivers - Analysis of proxy records

\section{Introduction}

The sedimentological, paleobiological, and chronological studies of the Late Pleistocene-Holocene cropping out in the middle fluvial valleys of the Undulated Pampa region of the Buenos Aires Province (locally known as the "Pampa Ondulada Bonaerense") allowed to identify different depositional units (DU), bounded by unconformities. Depositional units and their facies, as defined for the Luján river basin, were associated by Blasi et al. (2010) based on their stratigraphic position, chronological ages, and paleoclimatic and paleoenvironmental interpretations with different marine isotopic stages (MIS 4-2). As pointed out by Sowers (2000) the marine isotope record, which is the most complete record available of Quaternary climate cycles, is the standard to which we correlate other Quaternary paleoclimatic records.

The studied sequence lies in between the continental deposits and those of the corresponding marine isotopic stage. It offers a very valuable independence concerning the use of stratigraphic nomenclature (biostratigraphy, lithostratigraphy, chronostratigraphy, sequential stratigraphy, etc.) of different stratigraphic schemes established for the study area, generally based on relative chronologies (Blasi et al. 2009b). As pointed out by these authors, the large amount of formal and even informal stratigraphic terms for naming stratigraphic units locally and the use of synonyms for regional correlations eventually generated a nomenclature chaotic situation. These authors proposed to define stratigraphic schemes through the description of DU limited by unconformities, their lithofacies and facies variations.

The results obtained in the characterization of depositional unit 2 (DU2) are herein presented and explained. It is formed by one fluvial-lacustrine facies (F3) chronologically delimited and exposed in certain restricted areas of two large fluvial basins of the Undulated Pampa (the Luján and the Salto-Arrecifes rivers basins). Its association with the Marine Isotope Stage 3 (MIS 3) is discussed in this paper.

During the interstadial MIS 3, belonging to the last glacial stage, several climatic variations occurred with alternating warmer phases, the Dansgaard-Oeschger events (DO) and colder phases, known as the Heinrich events $(\mathrm{H})$, defined according to different proxies analyzed in Antarctic and Arctic polar ice cores (Bond et al. 1993; 
Clark et al. 2007; Van Meerbeeck et al. 2009; Rabassa and Ponce 2013; Sinddall et al. 2008). Climate variations taking place during that period somehow have affected the region under study and their consequences were recorded in the analyzed DU.

\section{Geological Setting}

The study area, in northeastern Buenos Aires Province, Argentina, is located within the "Pampa Levantada" ("raised Pampa") region (Pasotti 1971). It corresponds geomorphologically to the Pampa subregion called "Undulated Pampa" (Pasotti and Castellanos 1967) that covers part of the provinces of Buenos Aires, Córdoba and Santa $\mathrm{Fe}$, with an area of approximately $44,000 \mathrm{~km}^{2}$ (Fig. 1). It is characterized by the development of undulating landforms due to the presence of low hills aligned in a SW-NE direction and eroded by creeks, streamlets, and rivers. This undulating surface was produced by fluvial erosion and minor tectonic block movements, with differential displacement, associated with large faults related to the crystalline basement (Pasotti 1971, 1973, 2000).

Among other fluvial basins draining this region, those of the herein studied Luján and Salto-Arrecifes rivers are the most relevant for Quaternary studies. Both flow into the Parana de las Palmas, which is one of the distributaries of the lower portion of the Paraná river, demarcating the westem edge of the Río de La Plata delta (Fig. 1).

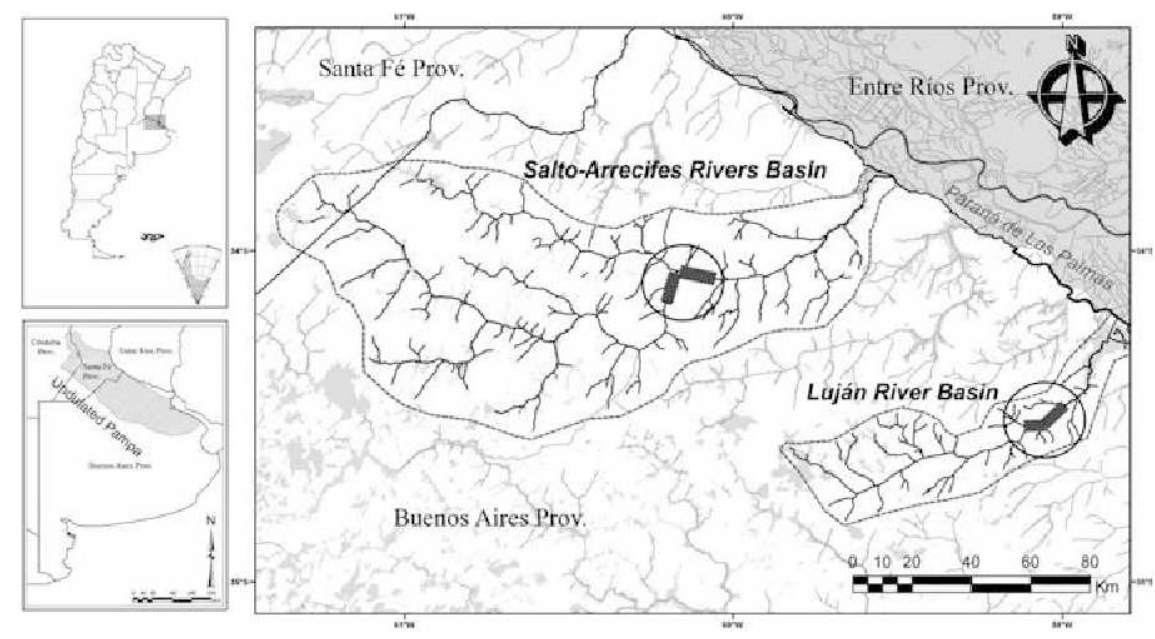

Fig. 1 Location map of the Lujän and Salto-Arrecifes basins showing location of MIS 3 sections and geographic features 
The Luján and Salto-Arrecifes stream basins initiate from small streamlets which in turn have their sources in shallow lacustrine water bodies. The main collectors appearing in the medium part of the basins are confined in most of the sections by very high cutbanks. Successive sediments exposed in the cutbanks show the paleoenvironmental and paleoclimatic evolution of the Late Pleistocene and Holocene of the Undulated Pampa valleys (Prieto et al. 2004; Blasi et al. 2010).

\section{Materials and Methods}

Information was gathered from seven localities at the Luján river basin and six other ones at the Salto-Arrecifes rivers basin (Fig. 1). The sedimentary facies exposed at the cutbanks of the studied localities were characterized by their colorimetric features (Munsell Color Chart), lithology, morphologic expression, and biological content. Samples were taken from each known facies, for sedimentological analysis as well as for their paleobiological and chronologic content $\left({ }^{14} \mathrm{C}\right.$ standard, AMS radiocarbon dating and IRSL).

Sedimentological analysis was accomplished according to standard methods (Carver 1971). The analysis comprised the elimination of organic material with a solution of $30 \% \mathrm{H}_{2} \mathrm{O}_{2}$, and of cementing materials with a solution of $35 \% \mathrm{HCl}$. For dispersion, $4 \%\left(\mathrm{NaPO}_{3}\right)_{6}$ and mechanical shaking were used. Grain size analysis for sand fraction was performed by sieving at half $\Phi$ intervals and by pipetting for the silt clay fraction grain size classification (Craver 1971). The gravel, sand, silt, and clay content percentages were used for the grain size classification according to Folk (1954). Mineralogical analysis was performed in the very fine sand fraction $(0.125-0.062 \mathrm{~mm})$ by polarization microscopy. Clay mineralogy was performed in preparation of total and oriented samples, using a Phillips Difractometer X-rays PW3710 Cu tube.

Samples for biosiliceous particle counting and identification were treated with $\left(\mathrm{NaPO}_{3}\right)_{6}$ for sediment disaggregation and clay removal. Then, $15 \mathrm{ml}$ of $35 \% \mathrm{HCl}$ was added and the solution was allowed to stand for $24 \mathrm{~h}$ to eliminate carbonate precipitation. Samples were rinsed several times with distilled water. Next, $10 \mathrm{ml}$ of $30 \% \mathrm{H}_{2} \mathrm{O}_{2}$ was added to eliminate organic matter and then the samples were boiled for $4 \mathrm{~h}$ and rinsed five times with distilled water. Permanent slides were mounted in Naphrax for counting and identification. A minimum of 400 biosiliceous particles was counted at $\times 1000$ magnification in each sample with an Olympus BX 40 microscope.

Phytoliths were identified according to Bozarth (1992), del Puerto et al. (2006), del Puerto (2009), Fredlund and Tieszen (1994), Fernández et al. (2006), Gallego and Distel (2004), Twiss (1992), and Zucol (1998, 2000, 2001). Although phytoliths cannot be assigned to individual grass taxa, different ratios of phytoliths (pooid, chloridoid and panicoid) may serve as climatic indices for paleoclimatic interpretations of a given region. In this sense, where the C3-types occur, the ratio 
C3 to C4 (Twiss 1992) can be used as an index of temperature following the equation: $\mathrm{TI}=($ Pooid $) /[$ (Pooid + Panicoid + Chloridoid $) * 100]$.

Higher values suggest a cooler climate in high latitudes or altitudes (where C3 are prevalent), and lower values suggest warmer temperatures that would be found in lower latitudes or elevations. Similarly, by comparing chloridoid to the sum of chloridoid and panicoid phytoliths a humidity index: $\mathrm{HI}=$ (Chloridoid)/ [(Chloridoid + Panicoid) * 100] may be obtained. Values close to 100 indicate an arid climate, whereas lower values indicate a humid climate. Diatom species were identified and classified according to Frenguelli $(1941,1945)$, Metzeltín and García-Rodríguez (2003), Metzeltín et al. (2005) and Witkowski et al. (2000). Chrysophycean cysts were identified according to Duff et al. (1995) and sponge spicules were recognized according to Ezcurra de Drago (1993).

Samples were washed under $0.5 \mathrm{~mm}$ mesh opening sieve to obtain and concentrate malacological species. Samples were observed under binocular glass $(40 \mathrm{X})$ where species were identifiedand measureded.

To the study of the ostracod fauna, samples were disaggregated with water and washed under a sieve of 63 microns (Tyler Screen System No. 230). All adults and juvenile specimens found in $1 \mathrm{~g}$ of dry sediment were picked up. The species were determined according to Moore and Pitrat (1961), Van Morkhoven (1963), Ramírez (1967), Bertels and Martínez (1990) and Ferrero (1996, 2009), among others.

Finally, in order to determine radiocarbon ages and ages through IRSL, samples were processed according to Blasi et al. (2010).

\section{Analyzed Stratigraphic Sections}

The sedimentary and paleobiological record of DU2 (Facies 3) exposed at the cutbanks of the Luján and Salto-Arrecifes rivers basins was sampled in a few places along the sections studied in both basins (Fig. 1). In these rivers, the deposits corresponding to this interval are circumscribed to the middle portion of the fluvial basins and were associated by Blasi et al. (2010) to the Marine Isotopic Stage 3. In the Luján river basin, it crops out in four clearly constrained sampling sites and in the Salto-Arrecifes rivers basin, in two sites (Table 1). Depending on the hydrologic state of the rivers, they are exposed in the middle to lower portion of the cutbanks (Fig. 2).

\section{Results}

The depositional unit 2 is formed by facies F3 (Blasi et al. 2010) and appears in massive lens shaped layers with variable thickness, from 1 to $1.30 \mathrm{~m}$ (Fig. 2). It rests in erosive to paraconcordant unconformity over the underlying depositional unit DU1/DU2 (Fig. 2). Below this unit, depositional unit 3 (DU3), (facies F4-F5) 
Table 1 Studied sections in the Lujän river and Salto-Arrecifes rivers, with the corresponding profiles

\begin{tabular}{|c|c|c|}
\hline & & Studied localities \\
\hline \multirow[t]{6}{*}{$\begin{array}{l}\text { UD2 } \\
\text { Facies } 3\end{array}$} & \multirow[t]{4}{*}{ Luján river } & $\begin{array}{l}\text { Profile Arroyo Sin Nombre (PASN) (34 } 34^{\prime} 54^{\prime \prime} \mathrm{S} / 59^{\circ} 10^{\prime} \\
\left.20^{\prime \prime} \mathrm{W}\right)\end{array}$ \\
\hline & & Profile Benedictinos (PBN) $\left(34^{\circ} 34^{\prime} 42^{\prime \prime} \mathrm{S} / 59^{\circ} 10^{\prime} 04^{\prime \prime} \mathrm{W}\right)$ \\
\hline & & 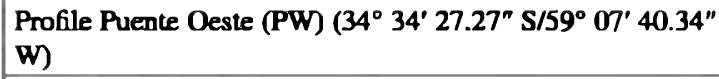 \\
\hline & & $\begin{array}{l}\text { Profile Molino Viejo (PMV) (34 34' 8.59" S/59 07' 29.04" } \\
\text { W) }\end{array}$ \\
\hline & \multirow[t]{2}{*}{$\begin{array}{l}\text { Salto-Arrecifes } \\
\text { rivers }\end{array}$} & $\begin{array}{l}\text { Profile Barranca Salto (PBS) }\left(34^{\circ} 8^{\prime} 14.3^{\prime \prime} \mathrm{S} / 60^{\circ} 11^{\prime} 16.9^{\prime \prime}\right. \\
\text { W) }\end{array}$ \\
\hline & & Profile Arrecifes (PAR) $\left(34^{\circ} 04^{\prime} 54.4^{\prime \prime} \mathrm{S} / 60^{\circ} 05^{\prime} 29.6^{\prime \prime} \mathrm{W}\right)$ \\
\hline
\end{tabular}

(a)

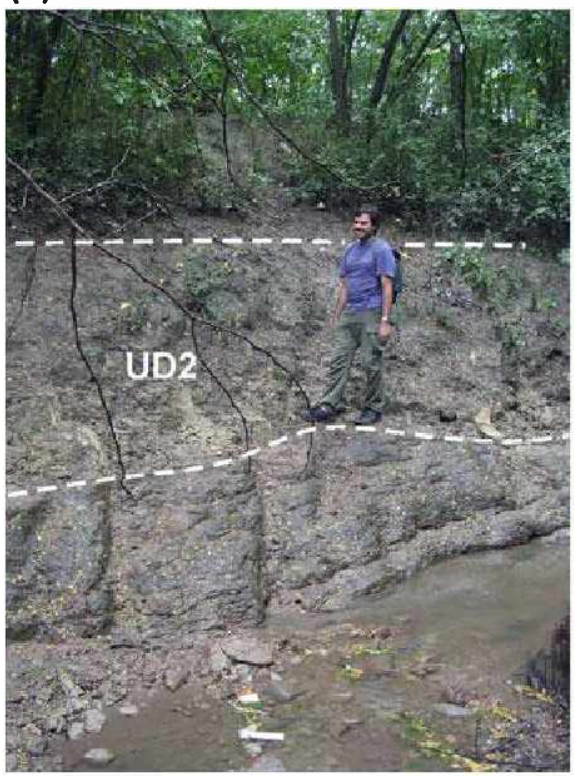

(b)

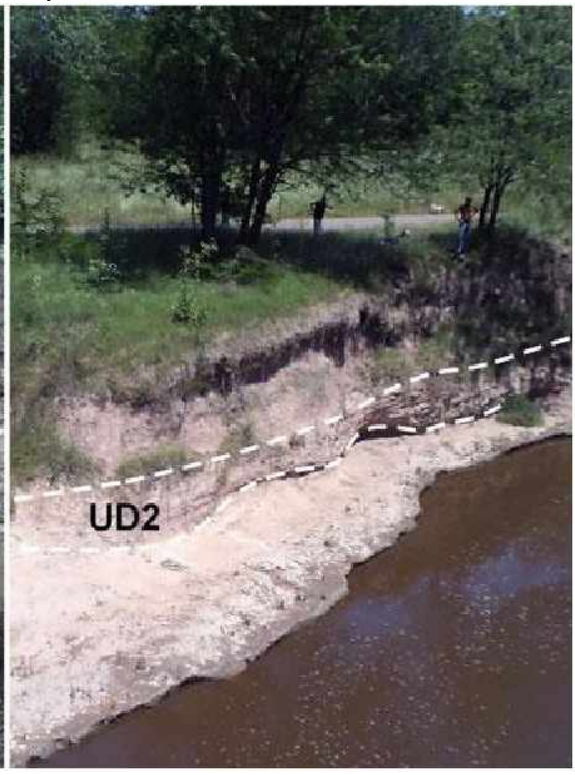

Fig. 2 Outcrops of depositional unit 2 (DU2) at the cut hanks. a Arroyo sin Nombre at Luján river section (Blasi et al. 2010); b Arrecifes river section

and/or lacustrine Holocene deposits occur in stratigraphic uniformity (Blasi et al. 2010). It is lithologically composed of sandy muddy gravel, gravelly muddy sand, and olive green gravelly mud (5Y 5/6) (Figs. 3, 4).

The gravel fraction is composed of fine-grained sedimentary lithic fragment (muddy intraclast), bioclasts (such as reworked bone fragments), and rounded to subrounded calcium carbonate clasts (calcretes fragments), larger than $2 \mathrm{~mm}$. The sandy fraction shows muddy intraclasts, rounded calcrete fragments, as well as, siliciclastic and bioclastic grains. Among the latter, quartz is predominant over 

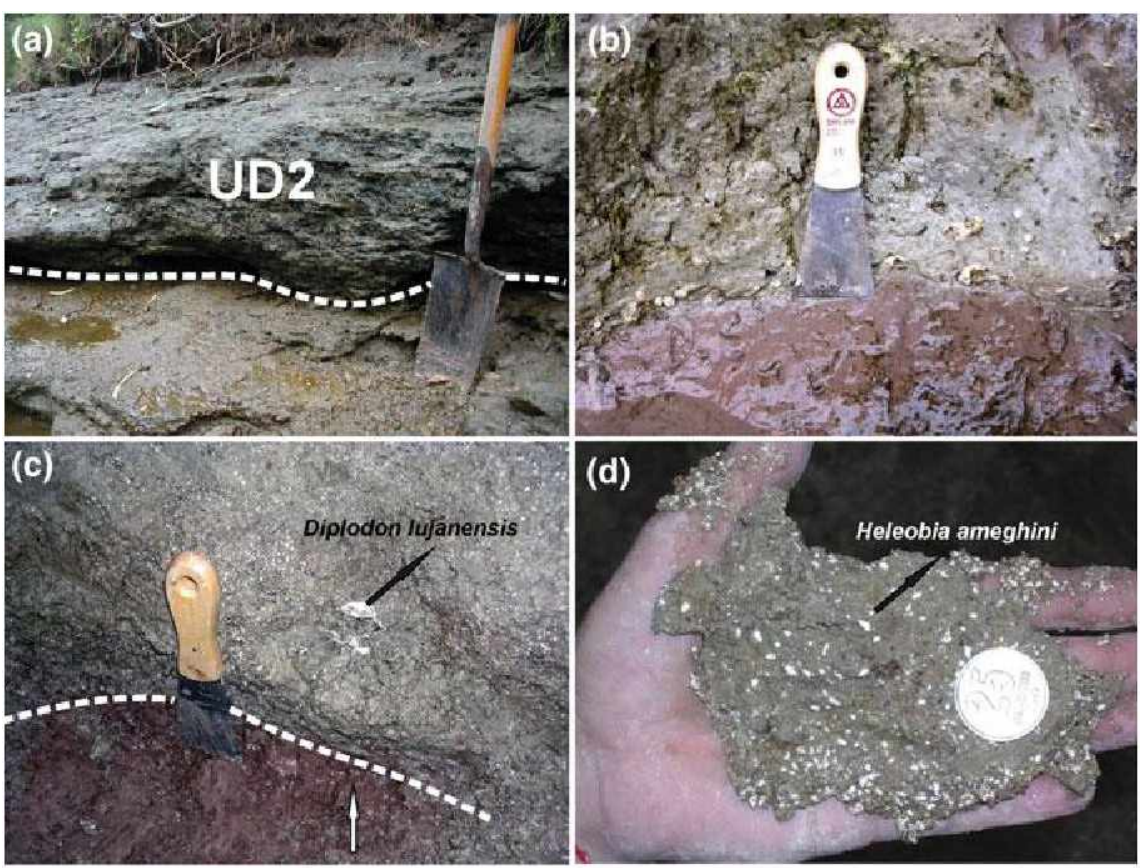

Fig. 3 Depositional unit 2 (DU2); a erosive contact between UD2 and UD1; b Net contact between olive green DU2 and red DU1, basal gravels of calcretes lithoclast; c UD2 olive green. gravelly muddy sand with Dipladon lujanensis shells; d Abundant shells of Heleobia ameghini in olive green, gravelly muddy sand

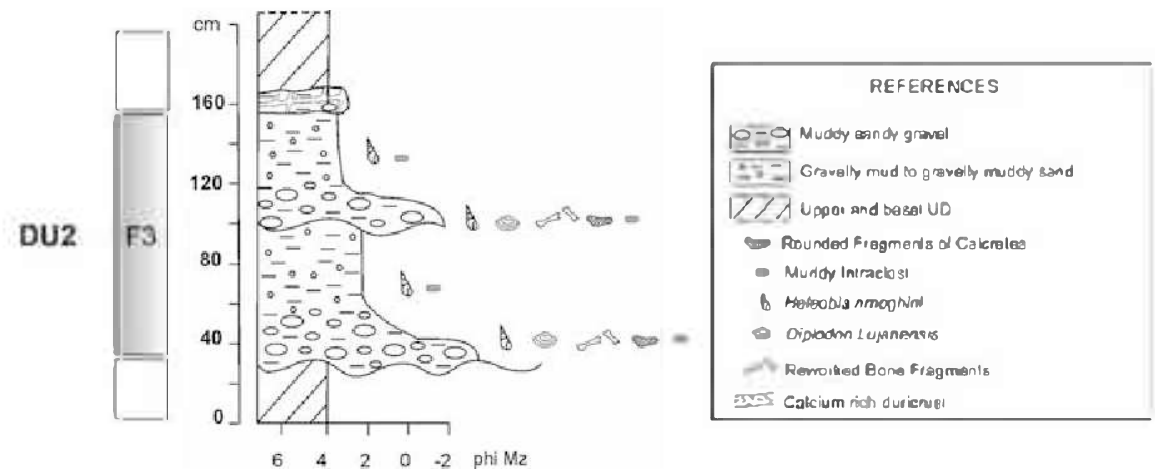

Fig. 4 Schematic model for the stratigraphic sequence of depositional unit 2-MIS 3 outcrops and lithostratigraphic column with depositional unit 2 (DU2) and Facies 3 characteristics

feldspar (mostly plagioclases) and some bioclasts such as small broken shell fragments and undetermined bone fragments. There are scarce volcanic glass shards. The clay fraction is represented by quartz, plagioclase, and clay minerals. 


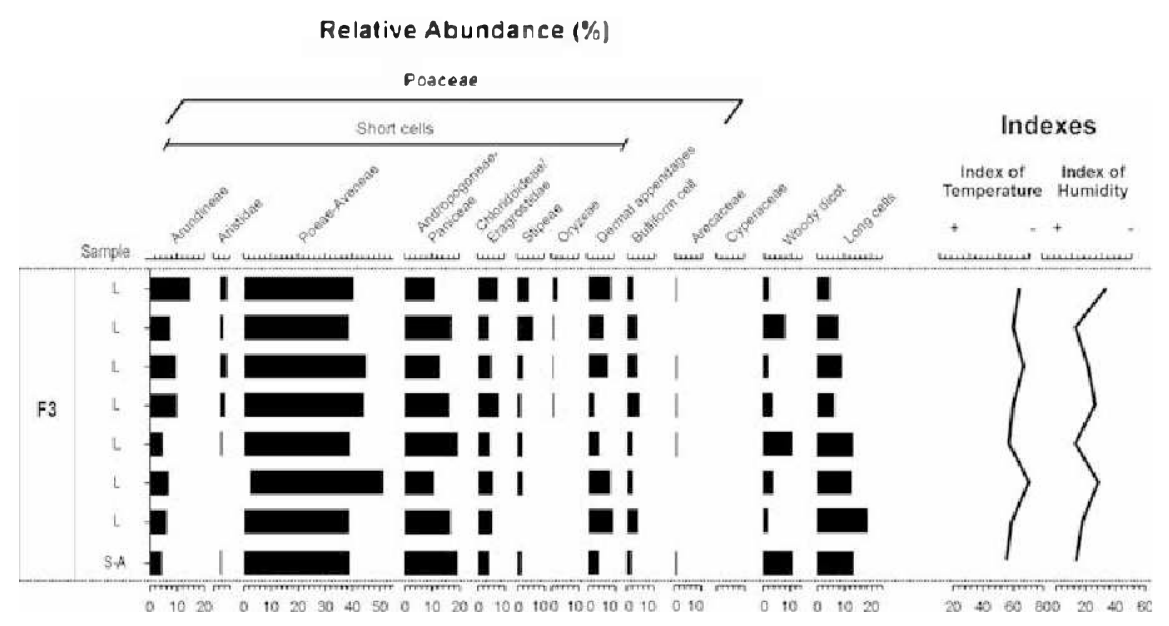

Fig. 5 Phytolytic diagram. Relative percentages of abundance of different gramineae morphotypes in samples from divense Luján river sections and Barranca Salto section. Index of temperature and humidity, in the different samples showing fluctuating in climatic conditions (modified from Blasi et al. 2010)

The crystals which appear with a small amount are gypsum/anhydrite and calcite/dolomite. Illite is the dominant clay mineral, and kaolinite occurs in a smaller proportion.

In the biosilica content there is a broad predominance of gramineae phytoliths. According to the identified morphotypes, short winter gramineae cells, mainly Avenae and Poeae tribes prevail. They are followed by morphotypes assigned to species of the subfamily Arundinoideae, mainly from the tribe Arundinae. This family has $\mathrm{C}_{4}$ species within the Aristidae (Aristide) tribe and $\mathrm{C}_{3}$ in the Arundinae tribe (e.g. Cortaderia Stapf). Other gramineae $C_{3}$ morphotypes correspond to the Oryzeae tribe. $\mathrm{C}_{4}$ species are mainly represented by morphotypes produced by the subfamilies Panicoideae and Chloridoideae (Fig. 5).

The diatom record shows abundance of the planktonic species Cyclotella meneghiniana Kützing. Other frequent oligohalobus and mesohalobous bentonic taxa are Amphora copulate (Kützing) Schoeman and R.E.M. Archibald, and Navicula peregrina, (Ehrenberg) Kützing, respectively. This association is also formed by epiphyte species such as Cocconeis placentula Ehrenberg with oligohalobus tychoplanktonic features, the halobius Fragilaria capucina Desmazières, and oligohalobus indifferent aerophiles such as Pinnularia borealis Ehrenberg (Table 2) (Fig. 6).

Two extinct mollusk species were identified: the gastropod Heleobia ameghini (Doering) and the bivalve Diplodon lujanensis Thering, (Blasi et al. 2010; De Francesco and Blasi 2012). In the Lujän river basin only one and abundant ostracod, Cyprideis salebrosa hartmanni Ramirez, was found. In the DU2 of the Salto-Arrecifes basin, C. salebrosa hartmanni represents the dominant fraction of 
The Marine Isotopic Stage 3 (MIS 3) in Valleys ...

Table 2 Relative frequency and ecological characteristics of the diatom taxa

\begin{tabular}{l|l|l|l|l|l}
\hline \multicolumn{2}{l|}{} & Diatom taxa & Abundance & Habitat & Salinity \\
\hline UD2 & Facies 3 & $\begin{array}{l}\text { Amphora copulata (Kütz.) } \\
\text { Schoeman \& Arch }\end{array}$ & F & B & OI \\
\cline { 3 - 5 } & $\begin{array}{l}\text { Anomoeoneis sphaerophora } \\
\text { (Ehr.) Pfitzer }\end{array}$ & S & B & OH \\
\hline & Cocconeis placentula Ehr. & F & E & OI \\
\hline & Cyclotella meneghiniana Kütz & A-VA & P & OH \\
\hline & Cymbella cymbiformis Ehr. & S & E & OI \\
\hline & Epithemia adnata (Kütz) Breb. & A & E & OI \\
\hline Navicula peregrina (Ehr.) Kütz & F-A & B & M \\
\hline & Nitzschia amphibia Grun. & A & Aer & OI \\
\hline & Pinnularia borealis Ehr. & F & Aer & OI \\
\hline & Surirella minuta Bréb. & R & B & Po \\
\hline & Tabularia tabulata Agandh & F & B & OH \\
\hline & $\begin{array}{l}\text { Gomphonema lujanensis } \\
\text { Reichardt \& Maidana }\end{array}$ & R & B & OI \\
\hline
\end{tabular}

References $F$ frequent, $S$ scarce, $A$ abundant, $V A$ very abundant, $R$ rare, $B$ benthic, $E$ epiphytic, $P$ planktonic, Aer aerphilous. $O$ oligobalobus indifferent, $O H$ oligohalobus halophyllus, $M$ mesobalobus, Po polybalobus
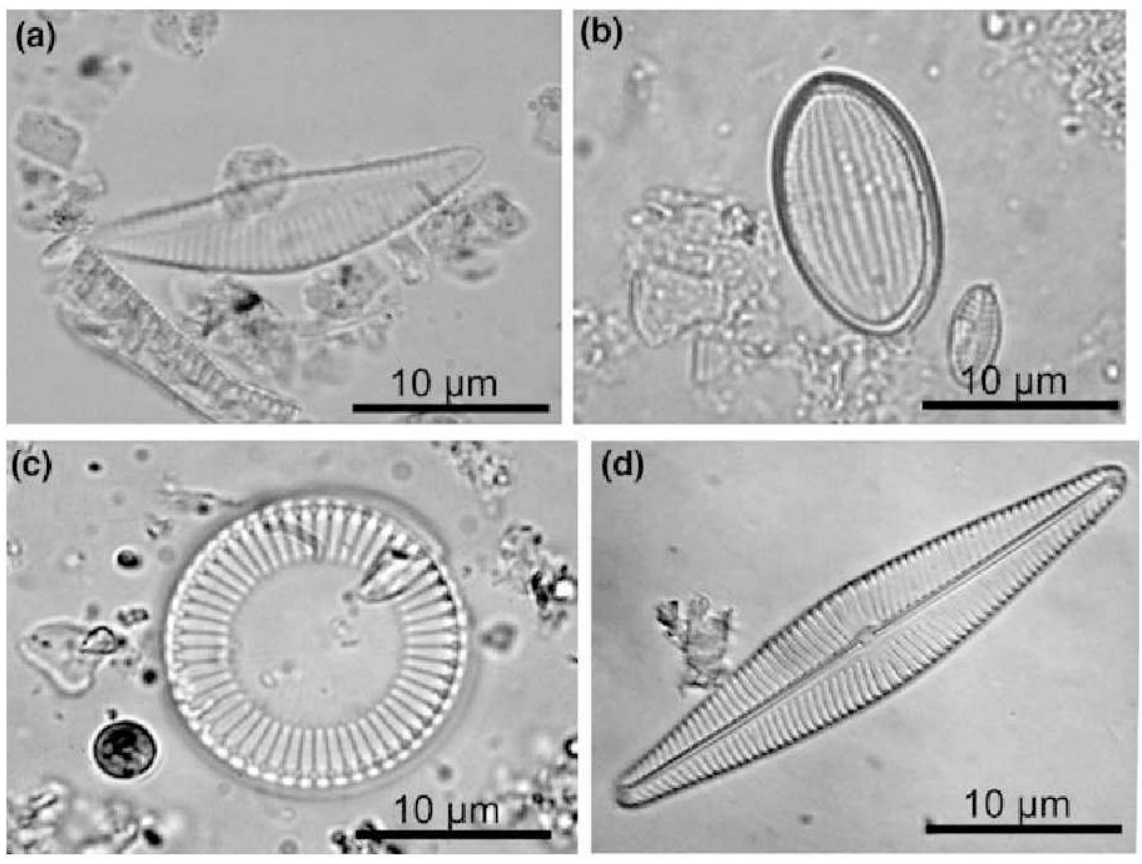

Fig. 6 The most abundant taxa of diatoms found in DU2. a Amphora copulate; b Cocconeis placensula; c Cyclotella meneghiniana; d Epithemia adnata 
the ostracod association; accompanied in a lesser extent by species of Limnocythere Brady and Iyocypris Brady and Norman. The ostracod association recovered from the DU2 is characterized by adult and juvenile specimens suggesting an autochthonous fauna (Boomer et al. 2003) (Fig. 7). Noteworthy, in the Arrecifes site (Table 1) and particularly in the DU2 deposits, bone remains that may be assigned to Megatherium Cuvier were found (S. Vizcaino, pers. comm.).

Radiocarbon ages were obtained from specimens of Cyprideis salebrosa hartmanni, Heleobia ameghini, and Diplodon lujanensis. In two cases, the ages were beyond the limits of the radiocarbon dating method. One age was also obtained by means of the IRSI. technique (Table 3).

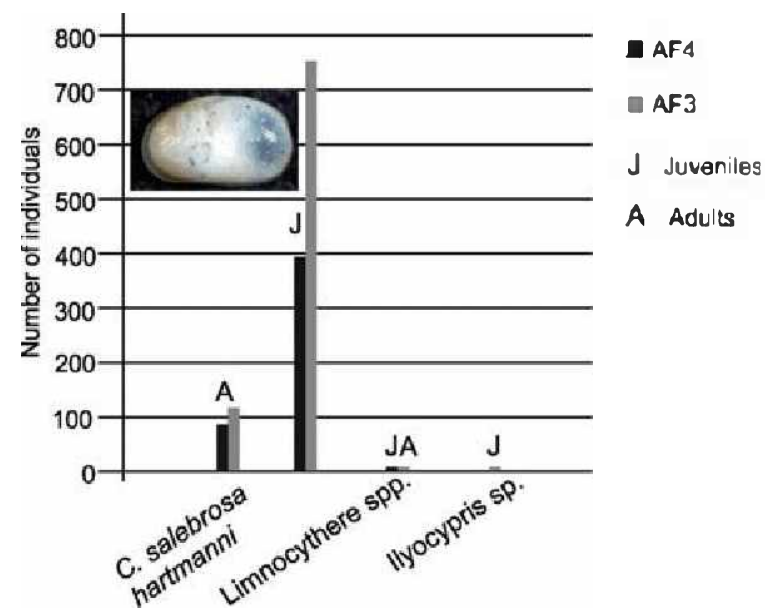

Fig. 7 Ostracod species and their abundance in DU2 for the Arrecifes river section; illustrated ostracod: Cyprideis salebrosa hartmanni, female left valve

Table 3 Radiocarton and IRSL dating

\begin{tabular}{|c|c|c|c|c|}
\hline $\begin{array}{l}\text { Age } \\
\left(\mathrm{a}^{14} \mathrm{C} \text { yr BP) }\right. \\
\text { (b: IRSL) }\end{array}$ & $\begin{array}{l}\text { Laboratory } \\
\text { number }\end{array}$ & Sample & $\begin{array}{l}\text { Geographic } \\
\text { coordinates }\end{array}$ & $\begin{array}{l}\text { Stratigraphic } \\
\text { assignment }\end{array}$ \\
\hline $37.710 \pm 840 a$ & $\begin{array}{l}\text { Beta- } \\
217826\end{array}$ & $\begin{array}{l}\text { Cyprideis } \\
\text { salebrosa } \\
\text { hartmanni }\end{array}$ & $\begin{array}{l}34^{\circ} 34^{\prime} 08^{n} \mathrm{~S} \\
59^{\circ} 07^{\prime} 29^{n} \mathrm{~W}\end{array}$ & \multirow{3}{*}{$\begin{array}{l}\text { UD2 } \\
\text { Lujấn river } \\
\text { (Blasi et al. } \\
\text { 2010) }\end{array}$} \\
\hline$>40.000 \mathrm{a}$ & LP-1733 & $\begin{array}{l}\text { Helobia } \\
\text { aneghini }\end{array}$ & $\begin{array}{l}34^{\circ} 34^{\prime} 55^{\prime \prime} \mathrm{S} \\
59^{\circ} 10^{\prime} 20^{n} \mathrm{~W}\end{array}$ & \\
\hline $44.000 \pm 6500 b$ & UNL-1928 & feldespar & $\begin{array}{l}34^{\circ} 34^{\prime} 08^{n} \mathrm{~S} \\
59^{\circ} 07^{\prime} 29^{\prime \prime} \mathrm{W}\end{array}$ & \\
\hline$>40.000 \mathrm{a}$ & LP-2985 & Diplodon sp. & $\begin{array}{l}34^{\circ} 04^{\prime} 4.4^{n} \mathrm{~S} \\
60^{\circ} 05^{\prime} 29^{n} \mathrm{~W}\end{array}$ & $\begin{array}{l}\text { UD2 } \\
\text { Salto-Arrocifes } \\
\text { rivers }\end{array}$ \\
\hline
\end{tabular}

Beta Beta Analytic; LP LATYR, La Plata; UNZ University of Nebraska, Lincoln 
It should be noted that the green color of DU2 was used to correlate outcroppings of the same color appearing in different basins of other geographic areas, independently from their stratigraphic or temporal location. It was also used as an informal stratigraphic nomenclature. Di Lello et al. (2009) determined by Mössbauer spectroscopy that the dark green color of a hermetically kept sample dried in argon atmosphere showed a couplet corresponding to about $10 \%$ spectra of ferrous iron $\left(\mathrm{Fe}^{2+}\right)$. Some authors suggested that this could come from minerals of the original sediment (such as ferrous illite), neoformed minerals, and incorporation and/or adsorption of ferrous ion in crystalline structures under negative Eh conditions.

\section{Paleoenvironmental Reconstruction}

The DU2 facies 3 was interpreted as a mixed or hybrid deposit (Pettijohn et al. 1987) with two origins: the deposit of detritus transported by channelized floods and sheet floods of sporadic flash floods generated by strong rains under arid climatic conditions or strongly seasonal, and decantation of very fine sand and muddy sediments in lentic bodies formed afterwards.

Channelized or sheet flows could have been drained to lower areas of the land carving numerous gullies or streamlets in older deposits (the DU1/facies F2). This mechanism is considered as the greatest provider and transporter of a large amount of sediments (sediment delivery, sensu Hooke and Mant 2002) in environments characterized by water deficit. At a later stage, gullies or streamlets could have experienced damming by deposition of the bedload (tractionload), originating the development of temporary pools or small lentic bodies. With another climatic fluctuation, a new cycle with channelized flows developed and subsequent small lentic bodies may have restarted. Intraformational clast-size gravel may have formed during the first stage of intense erosion due to sheet flows and streamlets runoff. These are formed by erosion and reworked older sediments, which act as source of fine-grained sedimentary lithoclast (muddy intraclast), fragments of calcretes (locally known as "tosca") and bone fragments. This coarse bedload is transported under high hydrodynamic flow conditions. At a later stage, sandy and/or sandy/muddy sediments may have accumulated among the high energy open gravels once a reduction of energy for load transport is produced. There may have also been some input of fine eolian vitroclastic material defined as sandy loess by Zárate and Blasi (1991) that may have been masked by large amounts of local alluvium deposits.

Temporary pools were formed by damming of streamlets, no major depositional processes occurred, and the diversities of diatoms, ostracods and mollusks are low. During wetter periods, there were probably flooding events and generation of lentic bodies with larger water surface. During the most arid periods, these meso- to eutrophic water lentic bodies may have undergone environmental stress due to the sharp fluctuation of water level, salinity, and temperature. That was probably the 
reason for the development of monospecific microfauna of ostracod, mollusk and diatom, such as Cyprideis salebrosa hartmanni, Heleobia amheghini, and Diplodom lujanensis, as well as frequent mesohalobuis algae (Navicula peregrina) which are tolerant of greater salinity. As mentioned before the ostracod association was dominated by $C$. salebrosa hartmanni together with species of Limnocythere and Iyocypris. Cyprideis is aeuryhaline genus which lives also in fresh to brackish waters, and is very adaptable to this type of environmental conditions. Ornellas and Wurdig (1983) found this species in hyposaline environments (0-29 psu) with a temperature range from 15 to $25^{\circ} \mathrm{C}$ in sandy silt sediments rich in organic matter and littoral vegetation. On the other hand, Ferrero $(1996,2009)$ suggested that this species is typical to brackish environments, and Ramírez (1967) mentioned it in limnic environments of Buenos Aires Province. The faunal association, recovered in this study suggests similar conditions, from fresh to oligohaline environments. Also, the abundance of aerophilous diatoms suggests that the water bodies or pools may have been intermittent or temporary; whereas the strong seasonal rain under temperate to colder climatic conditions would be evidenced by the larger presence of gramineae phytoliths $\mathrm{C} 3$ and a high representation of chloridoid morphotypes within C4.

\section{Correlation}

Blasi et al. (2010) correlated DU2 with the different stratigraphic units defined by different authors in the Luján area. In this way, DU2 is related to the "Pampeano Lacustre" terrain of "Villa de Luján" (layer 3), as it has been defined by Ameghino (1880-1881: 568) and Layers 5, 6, and 7 defined in Paso de Azpeitía (Ameghino 1880-1881: 567). Furthermore, DU2 correlates with the deposits assigned to the true "Piso Pampeano Lacustre" (layers 9, 8 and 7) by Ameghino (1884: 165) and with the "Piso Lujanense" (following Ameghino 1889).

This unit is also correlated with the yellowish green, sandy and nodular, lacustrine sediment bearing mammal remains of the "Bonaerense lacustre" or "Lujanense" beds as defined by Rovereto (1914). It also correlates with the "Prebonaerense" stage of Frenguelli (1921: 66) and/or the "Lujanense" beds of Frenguelli (1928). There are also similarities with the Units1 A and B as defined by Dangavs and Blasi (1995) in the Luján river, (Blasi et al. 2010).

Recently, Toledo (2011) included an unconformity named as "Interlujanense" in the stratigraphic scheme of Ameghino (1880-1881), overlying a greenish, fining upward sequence with radiocarbon ages from $46,500 \pm 4000$ years ${ }^{14} \mathrm{C}$ B.P. to $32,000 \pm 1400$ years ${ }^{14} \mathrm{C}$ B.P., (the "Lujanense Verde Inferior" sequence). Above the unconformity is another fining upward deposit, (the "Lujanense Rojo" sequence), that starts with a basal conglomerate.

In this sense, most of the UD2 discussed in this paper may be correlated with the depositional sequence "Lujanense Verde Inferior" ("Lower Green Lujanense") or the Jáuregui Member of the Luján Formation (Toledo 2011), whereas an upper 
portion of the DU2 (the upper conglomerate level shown in Fig. 3) may be correlated with the level defined by Toledo (2011) as basis for the "Lujanense Rojo" ("Red Lujanense depositional sequence") or basal section of the La Eloísa Member of the Luján Formation.

It should be noted that the Luján Formation was defined by Fidalgo et al. (1973) for the Río Salado basin (Blasi et al. 2009b) and that this lithostratigraphic unit was subdivided in two members: the Guerrero and Río Salado members.

However, Toledo (2011) created another Luján Formation, to define the Late Pleistocene interval of the previously Luján Formation as defined by Fidalgo et al. (1973). Similarly, the Luján Formation is renamed by Toledo (2011) (in its Holocene or Río Salado member portion, Fidalgo et al. 1973) as a new lithostratigraphic unit called the La Plata Formation. However, this author was not in compliance with the provisions of the Argentine Stratigraphic Nomenclature Code (Comité Argentino de Estratigrafía 1992), Sect. 31.13 (page 29) on Lithostratigraphic Units, which specifies that no identical name given to a previous lithostratigraphic unit can be used for a new one.

\section{Why Is UD2 (MIS3) Present Only in Short and Middle Areas of the River Basins?}

The depositional unit DU2 has only been recognized in restricted and discontinued areas of sections located in the middle portion of the fluvial basins (Fig. 1). This information is quite significant for the understanding of the evolution of the area from the Late Pleistocene to the Holocene, and contributes to the paleontological research, limiting the expectations of finding fossil remains plausible of being assigned to the interval $60,000-30,000$ years B.P. The DU2 could be observed only in streches about $7 \mathrm{~km}$ long in the main course of the Luján river basin and up to the present, this is the same for the Salto-Arrecifes rivers basin (Fig. 1).

In order to explain the reasons for the absence of outcrops of DU2 upstream and downstream of the mentioned stretches, some hypotheses may be proposed to be tested in future works. Although they are not the object of this work, so far, it is believed that these hypotheses are relevant in the context of this chapter.

Hypothesis 1: This phenomenon could be related to the existence, within the interval of accumulation of DU2 of the "parallel ravine model" posed by Pasotti (1971, 1973).

Pasotti $(1972,1973)$ posed for the first time the question that the "Undulated Pampa" could show the overlapping of two hydrological models formed at two different times. During the Pleistocene, the "Collinear" paleomodel of "parallel ravine model" and/or "last paleomodel" would have been active; in turn, during the Holocene, the hydrographic network developed the present ("grilled") configuration. The collinear model is represented by a series of straight paleo-ravines parallel to each other, regularly separated, which formed no hierarchical networks, SW-NE 
bound, with high gradient draining a eastern more bound, "broad and uniform" Pampa (Pasotti 1971, 1973, 1974, 2000). Pasotti (1972) stated that these models appear from the Saladillo river up to Arroyo del Medio (at the Santa Fe-Buenos Aires provincial border) and in the "Pampa Bonaerense", "farther south than the Arrecifes river". According to this author, the present networks cut the paleo-ravines at differing angles (straight and obtuse) which, in some cases, match those of the older network, but only in short stretches. In 1971-1973 Pasotti stated: "I think this network is the last of Pleistocene age and I named it as the last paleo-model" (Pasotti 2000: 4; free translation by the present authors). "The present hydrographic networks superpose the previous one, cutting the ravines or streamlets with differing angles that due to tectonics match only as an exception and in short stretches" (Pasotti 1971, 1973).

These ideas allowed the present authors to formulate the second hypothesis:

Hypothesis 2: The small area where DU2 can be found is due not only to the present network overlapping with the Pleistocene draining network (ravines) but also to a differential tectonic control that caused that this unit could only be observed at the base of cut banks in stretches coincident with raised tectonic blocks.

Neotectonic records of the Argentine Pampa plains were studied by Brunetto and Iriondo (2007). These authors developed several analyses including studies of the structural alignments, identification of geomorphological units and topographic features, from the interpretation of satellite images and field observations, thus being able to demarcate structural blocks. They also referred that the changes exerted by such structural elements on the direction of the superficial drainage allowed for the existence of some degree of deformation during the Late Pleistocene.

More recently, Racca (2010) in his regional scale studies on Arroyo del Medio fluvial basin (provincial boundary between the Provinces of Santa Fe and Buenos Aires), related the origin of greater-sized landforms (alignment) within the basin to neotectonic factors. Therefore, according to the this author, the study area would be affected by large movements due to very recent tectonic events (Holocene) that may have modified the existing of extremely flat topography (Late Pleistocene) and Pasotti's collinear model (1972). This highlights that the macromorphology of the area under study would have tectonic origin, minimizing the possible influence of paleoclimatic variability.

For the area of the Río de La Plata, Cavallotto (2002) concluded that through the pre-Holocene general topographic characteristics, the existence of a tectonic control shown by transversally oriented river alignments had been identified. On the other hand, the differences in radiometric values of the elevation of the Holocene maximum sea transgression registered along the Argentine coast would also reflect perhaps a neotectonic influence (Codignotto et al. 1992). 


\section{Conclusions}

The depositional unit 2 (DU2) overlies an erosive unconformity on eolian sediment with IRSL ages of $\sim 56,400 \pm 6500$ and 50,400 $\pm 10,200$ years. These sediments are also overlain by sandy loess deposits of the same eolian genesis (UD3, in Blasi et al. 2010) dated ca. 32,500 \pm 4100 years (IRSL) (Blasi et al. 2010).

Ages obtained for the lower and the upper DU2 deposits suggest an association with the Marine Isotopic Stage 3.

For this unit (DU2) a fluvial-lacustrine facies (F3) has been identified, representing ephemeral fluvial streams with gullies or streamlets formed during instantaneous rainstorm episodes and development of temporary pools of eutotrophic to distrophic characteristics formed by subsequent damming of the channels. The dominant lithology is sandy gravelly mud. These sediments are hybrid or mixed deposit according to Pettijohn et al. (1987), with predominance in the gravel size fraction of muddy intraclast, rounded fragments of calcretes ("tosca") and pebbled of bones. The sandy fraction is mainly quartz in composition. The scarce presence of volcanic glass in its petrographic characteristics should also be noted, whereas clay minerals are mainly illite.

Olive green coloring is highlighted by the presence of reduced iron ions in the illitic clay matrix (Di Lello et al. 2009). Some authors suggested that it could have originated in the alteration of detrital illite clay and/or adsorption of ferrous ion in crystalline structures under Eh negative conditions. Therefore, this attribute could repeat itself in any sector of the stratigraphic columns that may have been modified by the same processes.

Another relevant feature is the presence of mollusk species such as Diplodon lujanensis and Heleobia ameghini, that lack representation in modern fauna and which constitute an exceptional case for the Late Quaternary of Argentina (De Francesco and Blasi 2012).

Ages ascribed to the MIS3 were obtained from specimens of Cyprideis salebrosa hartmanni, Heleobia ameghini, and Diplodon lujanensis. In two cases, the obtained ages were beyond the accepted, reliable limits of the radiocarbon dating method. Age was also obtained through the IRSL technique. Climatic conditions inferred for the DU2 deposits were from rather temperate to colder, with subhumidhumid and subhumid-drier phases or strongly seasonal.

Likewise, the following questions were raised: Did the Luján and the Salto-Arrecifes rivers basins flow in the Late Pleistocene (during MIS3) as gullies or ephemeral stream lets subparallel to each other with high gradient and drainage courses with SW-NE direction? Have the geofractures associated with the crystalline basement and minor fractures in the sedimentary filling been active during the Holocene? And therefore, is there tectonic control over the present configuration of drainage networks and exposition of sequences associated with the MIS3? Can the superposition of both models be located in some uplifted blocks, and thus explain that they only appear in the referred stretches? 
Acknowledgments The authors thank E. Apolinaire for his assistance with the edition of the maps. Special thanks to the Editorial Committee for the invitation to participate in this publication. Reviews by Cecilia Deschamps, Jorge Rabassa and Germán M. Gasparini referees improved the manuscript. This work was supported by CONICET-PIP 5086 and CONICET-PIP 0342; Ostracod studies (by G.C. and A.C.) were supported by ANPCyT-PICT 2010-0082 and 2014-1271, CONICET-PIP 819 and CONICET-PIP 0021, and UNCo B 166.

\section{References}

Ameghino F (1880-1881) La Antigüedad del Hombre en el Plata. Oficina de Gobierno Provincia de Buenos Aires, La Plata

Ameghino F (1884) Excursiones geológicas y paleontológicas en la provincia de Buenos Aires. Boletín Academia Nacional de Ciencias de Córdoba VI:161-257

Ameghino F (1889) Contribución al conocimiento de los mamíferos fósiles de la República Argentina. Academia Nacional de Ciencias (Córdoba) 6:1-102

Bertels A, Martínez D (1990) Quaternary ostracodes of continental and transicional littoral shallow marine environments. Courier Forschungsinstitut Senckenberg 123:141-159

Blasi A, Hanson P, Fucks E, Prieto A, Young A (2009a) Infrared stimulated luminescence (IRSL) dating of late Pleistocene deposits from the middle course of the Luján river. Argentina. In: Actas IV Congreso Argentino de Cuaternario y Geomorfología, XII Congresso da Associação Brasileira de Estudos do Quaternário and II Reunión sobre el Cuaternario de América del Sur, La Plata, p 228

Blasi A, Prieto A, Fucks E, Figini A (2009b) Análisis de las nomenclaturas y de los esquemas estratigráficos del Pleistoceno tardío-Holoceno en la cuenca del río Lujan, Buenos Aires, Argentina. Ameghiniana 46(2):373-390

Blasi A, Castiñeira C, del Puerto L, Prieto A, Fucks E, de Francesco C, Hanson P, García-Rodriguez F, Huarte R, Carbonari J, Young A (2010) Paleoambientes de la Cuenca Media del río Luján (Buenos Aires, Argentina) durante el último Período Glacial (EIO 4-2). Lat Am J Sedimentol Basin Anal 17(2):85-112

Bond G, Broecker W, Johnsen S, Mc Manus J, Labeyrie L, Jouzel J, Bonani G (1993) Correlations between climate records from North Atlantic sediments and Greenland ice. Nature 365:143-147

Boomer I, Horne DJ, Slipper IJ (2003) The use of ostracods in Palaeoenvironmental studies, or what can you do with an ostracod shell? Paleontol Soc Pap 9:153-180

Bozarth S (1992) Classification of opal phytoliths formed in selected dicotyledons native to the Great Plains. In: Rapp G, Mulholland S (eds) Phytolith Systematics. Plenum, Nueva York

Brunetto E, Iriondo M (2007) Neotectónica en la Pampa norte (Argentina). Revista de la Sociedad Geológica de España 20(1-2):17-29

Cavallotto JL (2002) Evolución holocena de la llanura costera del margen sur del Río de la Plata. Rev Asoc Geol Argent 57:376-388

Carver R (1971) Procedures in Sedimentary Petrology. Wiley, New York

Clark P, Hostetler SW, Pisias NG, Schmittner A, Meissner KJ (2007) Mechanisms for a 7-Kyr climate and sea-level oscillation during marine isotope stage 3. In: Schmitter A, Chiang J, Hemming S (eds) Ocean circulation: mechanisms and impacts. American Geophysical Union, Geophysical Monograph 173, Washington

Codignotto JO, Kokot R, Marcomini S (1992) Neotectonism and sea-level changes in the coastal zone of Argentina. J Coastal Res 8(1):125-133

Comité Argentino de Estratigrafía (CAE) (1992) Código Argentino de Estratigrafía. Asociación Geológica Argentina Serie B Nº, Buenos Aires, 20:1-64

Dangavs N, Blasi A (1995) El Lujanense y Platense (sensu Ameghino) en el Río Luján, Luján, Provincia de Buenos Aires. In: Actas IV Jornadas Geológicas y Geofísicas Bonaerenses, Junín, (I):109-117 
De Francesco C, Blasi A (2012) Redescripción y significado paleoambiental de Heleobia ameghini (Doering, 1882) (Gastropoda: Rissooidea) en el Pleistoceno tardío de la provincia de Buenos Aires, Argentina. Ameghiniana 49:17-25

del Puerto L (2009) Silicofitolitos como Indicadores Paleoambientales: Bases comparativas y reconstrucción paleoclimática desde el Pleistoceno tardío en el SE del Uruguay. Pedeciba-Facultad de Ciencias de la Universidad de la República, Montevideo

del Puerto L, García-Rodríguez F, Inda H, Bracco R, Castiñeira C, Adams JB (2006) Paleolimnological evidence of Holocene paleoclimatic changes in Lake Blanca, southern Uruguay. J Paleolimnol 36:151-163

Di Lello C, Blasi A, Mercader R, Desimoni J (2009) El color de los sedimentos fluvio-lacustres del Pleistoceno tardío en la cuenca media del río Luján, provincia de Buenos Aires, Argentina. I Reunión Argentina de Geoquímica de la Superficie, Córdoba, 1:17

Duff K, Zeeb B, Smol J (1995) Atlas of chrysophycean cysts. Developments hydrobiology 99. Kluwer Academic, Dordecht

Ezcurra de Drago I (1993) Distribución geográfica de las esponjas Argentinas (Porifera: Spongillidae, Potamolepidae y Metaniidae). In: Boltovskoy L (ed) Relaciones zoogeográficas y vías de poblamiento. Instituto de Limnología "Dr. Raúl A. Ringuelet", La Plata

Fernández M, Zucol A, Osterrieth M (2006) Phytolith assemblages and systematic associations in grassland species of the south-Eastern Pampean Plains, Argentina. Ann Bot 98:1155-1165

Ferrero L (1996) Paleoecología de ostrácodos holocenos del estuario del río Quequén Grande (Provincia de Buenos Aires). Ameghiniana 33:209-222

Ferrero L (2009) Foraminíferos y ostrácodos del Pleistoceno tardío (Mar Chiquita, provincia de Buenos Aires, Argentina). Ameghiniana 46:637-656

Fidalgo F, De Francesco F, Colado U (1973) Geología superficial en las hojas Castelli, J. M. Cobo y Monasterio (Pcia. de Bs. As.). V Congreso Geológico Argentino, Actas, Carlos Paz, IV:2739

Fredlund GG, Tieszen LT (1994) Modern phytolith assemblages from the North American Great Plains. J Biogeogr 21:312-335

Frenguelli J (1921) Los Terrenos de la Costa Atlántica en los alrededores de Miramar (Prov. de Buenos Aires) y sus correlaciones. Boletín de la Academia Nacional de Ciencias de Córdoba XXIV:325-485

Frenguelli J (1928) Observaciones geológicas en la región costera sur de la Provincia de Buenos Aires. Anales de la Facultad de Ciencias de la Educación II:1-145

Frenguelli J (1941) Diatomeas del Río de la Plata. Rev Museo Plata 3:213-334

Frenguelli J (1945) Las diatomeas del Platense. Revista del Museo de La Plata, III:77-221

Folk RL (1954) The distinction between grain size and mineral composition in sedimentary rock nomenclature. J Geol 62(4):344-359

Gallego L, Distel R (2004) Phytolith assemblages in grasses native to Central Argentina. Ann Bot 94:865-874

Hooke JM, Mant JM (2002) Morpho-dynamics of ephemeral streams. In: Bull LJ, Kirkby MJ (eds) Dryland rivers. Wiley, Chichester

Metzeltín D, García-Rodríguez F (2003) Las Diatomeas Uruguayas. DIRAC, Montevideo

Metzeltín D, Langebertalot H, Garcia-Rodríguez F (2005) Diatoms of Uruguay: taxonomy, biogeography, diversity. In: Lange-Bertalot H. (ed) Iconographia Diatomologica 15. A.R.G. Gantner Verlag, Koenigstein

Moore RC, Pitrat CW (1961) Treatise on invertebrate paleontology. Part Q. Arthropoda 3. Crustacea, Ostracoda. Geological Society of America and University of Kansas Press, New York

Ornellas LP, Wurdig N (1983) Cyprideis salebrosa hartmanni Ramirez, F., 1967, A new subspecies from Brazil and Argentina. Pesquizas 15:94-112

Pasotti P (1971) Influencia de un Paleomodelo de red hidrográfica en la llanura de Santa Fé. In: Quinto Congreso Nacional del Agua, Santa Fe

Pasotti P (1972) Sobre la existencia de un Paleomodelo de red hidrográfica en la Provincia de Santa Fe. Boletín Filial Rosario, Sociedad Argentina de Estudios Geográficos GÆA 5, Rosario 
Pasotti P (1973) Sobre la presencia del último paleomodelo de red hidrográfica de edad pleistocénica en la llanura de la Provincia de Santa Fe. Publicaciones del Instituto de Fisiografía y Geología 57, Rosario

Pasotti P (1974) La Neotectónica en la llanura pampeana. Fundamentos para el mapa neotectónico. Publicaciones del Instituto de Fisiografía y Geología 58, Rosario

Pasotti P (2000) La geomorfología de la llanura pampeana en territorio santafesino. Boletín del Instituto de Fisiografía y Geología 70 (1-2):11-13, Rosario

Pasotti P, Castellanos A (1967) Rasgos morfológicos generales de la llanura pampeana. Conferencia Regional Latinoamericana de U.G.I., México, In: Boletín de la Filial Rosario de la Sociedad Argentina de Estudios Geográficos 3

Pettijohn FJ, Potter PE, Siever R (1987) Sand and sandstone. 2nd edn. Springer, New York

Prieto AR, Blasi A, De Francesco C, Fernández C (2004) Environmental history since $11,000{ }^{14} \mathrm{C}$ yr B.P. of the northeastern Pampas, Argentina, from alluvial sequences of the Luján river. Quatern Res 62(2):146-161

Rabassa J, Ponce JF (2013) The Heinrich and Dansgaard-Oeschger climatic events during Marine Isotopic Stage 3: Searching for appropriate times for human colonization of the Americas. Quatern Int 299:94-105

Racca JMG (2010) Geomorfología de la Cuenca del Arroyo del Medio. Boletín del Instituto de Fisiografía y Geología, Rosario, 72-75:13-42

Ramírez F (1967) Ostrácodos de Lagunas de la Provincia de Buenos Aires. Revista del Museo de La Plata X:5-54

Rovereto G (1914) Studi di Geomorfología Argentina. IV. La Pampa. Bolletino della Societá Geologica Italiana XXXIII:75-129

Sinddall M, Rohling EJ, Thompson WG, Waelbroeck C (2008) Marine isotope stage 3 sea level fluctuations: data synthesis and new outlook. Rev Geophys 46:1-29

Sowers J (2000) Correlating quaternary landforms and deposits to global climate change. In: Noller JS, Sowers JM, Lettis WR (eds) Quaternary geochronology. Methods and Applications. American Geophysical Union, Washington, DC

Toledo M (2011) El Legado Lujanense de Ameghino: revisión estratigráfica de los depósitos Pleistocenos-Holocenos del valle del río Luján en su sección tipo. Registro paleoclimático en la Pampa de los estadios OIS 4 al OIS 1. Revista de la Asociación Geológica Argentina 68 (1):121-167

Twiss P (1992) Predicted world distribution of C3 and C4 grass phytoliths. In: Rapp G, Mulholland S (eds) Phytolith systematic: emerging issues. Advances in archaeological and museum science, vol 1. Plenum Press, New York

Van Meerbeeck CJ, Renssen H, Roche DM (2009) How did marine isotope stage 3 and last maximum climates differ?-Perspectives from equilibrium simulations. Clim Past 5:33-51

Van Morkhoven FPCM (1963) Post-palaeozoic Ostracoda. Their morphology, taxonomy and economic use. Elsevier, Amsterdam

Witkowski A, Lange-Bertalot H, Metzeltin D (2000) Diatom flora of marine coasts. In: Lange-Bertalot $\mathbf{H}$ (ed). Iconograhia diatomologic, vol.7 Koeltz Scientific, Koeingstein

Zárate M, Blasi A (1991) Late Pleistocene and Holocene loess deposits of the Southeastern Buenos Aires Province, Argentina. GeoJoumal 24:211-220

Zucol AF (1998) Microfitolitos de las Poaceae Argentinas: II. Microfitolitos foliares de algunas especies del género Panicum (Poaceae, Paniceae), en la provincia de Entre Ríos. Darwiniana 36:29-50

Zucol AF (2000) Fitolitos de poaceae de Argentina: III. Fitolitos foliares de especies del género Paspalum (Paniceae), en la Provincia de Entre Ríos. Darwiniana 38:11-32

Zucol AF (2001) Fitolitos III. Una nueva metodología descriptiva. Asociaciones fotolíticas de Piptochaetium montevidense (Stipeae, Poaceae). Boletín de la Sociedad Argentina de Botánica 36:69-85 